\title{
Riglyne vir skryf
}

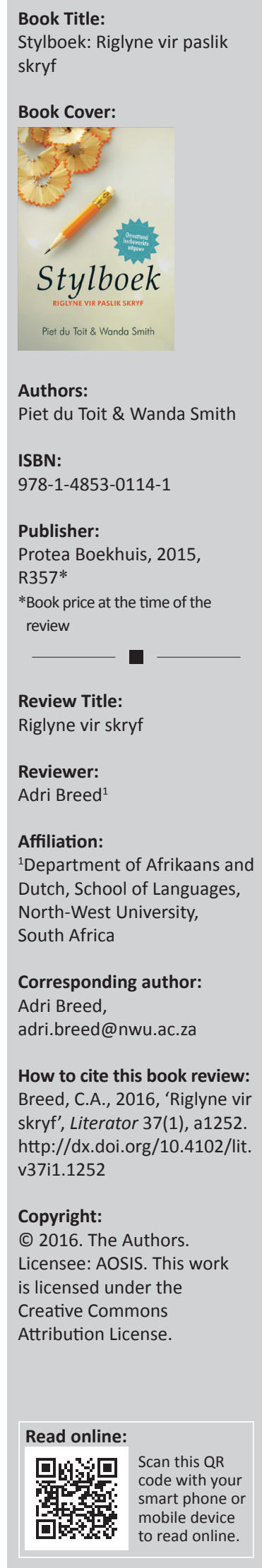

Ten einde Piet du Toit en Wanda Smith se 'omvattend herbewerkte uitgawe' van Stylboek: Riglyne vir paslik skryf (2015) te resenseer, is dit sinvol om dit met die 2003-uitgawe (met dieselfde titel) te vergelyk. Die eerste uitgawe is immers 'die eerste volwaardige stylhandboek in Afrikaans wat uitsluitlik op klassieke stylbeginsels fokus' en is al vir 'n hele aantal jare een van die belangrikste handboeke wat gebruik word om vir studente iets oor gepaste skryfstyl te leer. Die vraag kan gevra word of ' $n$ nuwe uitgawe werklik nodig was en of hierdie nuwe uitgawe die vorige uitgawe behoort te vervang.

Hoewel die 2003-uitgawe oor die algemeen goed deur lesers ontvang is, is daar in sommige resensies wel enkele punte van kritiek geopper. Jan Vorster (Die Burger, 20 Oktober 2003) skryf byvoorbeeld dat 'die boek kennelik nie geskik [is] vir juis die studente wat hulp nodig het nie' en dat die toon van die boek nie geskik vir sy lesersmark is nie. Mariana Venter verduidelik in Literator 25(2) '... om egter die maksimum waarde hieruit te verkry, vereis alreeds 'n sekere vaardigheidsgraad van die leser of toepasser van die wenke wat uit die voorbeeld en oefeninge afgelei kan word. 'n Heel onervare skrywer/leser sal dit selfs nodig vind om sommige voorbeelde herhaaldelik en met konsentrasie te lees', en Neil Cochrane sluit sy resensie in Tydskrif vir Geesteswetenskappe 41(1) met die volgende siening af: '... die skrywers moet gelukgewens word met hul inisiatief, maar die boek laat tog ruimte vir verbetering'.

Die bedoeling is natuurlik nie om weer van nuuts af die 2003-uitgawe te resenseer nie, maar die prysenswaardigheid van die 2015-uitgawe is juis die mate waartoe die skrywers gehoor gegee het aan die behoeftes van hulle lesers en die eerste uitgawe as 'n totale nuwe en uiters bruikbare handboek herskryf het.

Waar die 2003-uitgawe uit slegs 173 bladsye bestaan het, beslaan die nuwe uitgawe meer as 600 bladsye. Die 2003-uitgawe bevat sewe kort hoofstukke wat saamgestel is uit twee inleidende hoofstukke, vier hoofstukke wat elk een van die vier stylbeginsels (duidelikheid, bondigheid, gepaste toon en aantreklikheid) bespreek en 'n slothoofstuk wat die styl van wetenskaplike tekste bespreek. Die 2015-uitgawe bestaan uit twee afdelings. Die eerste afdeling se hoofstukindeling stem in 'n groot mate ooreen met dié van die eerste uitgawe, maar 'n agtste hoofstuk, 'Reg of verkeerd', is by hierdie afdeling gevoeg. In die tweede afdeling word 'n negende hoofstuk met heeltemal nuwe inhoud aangebied, naamlik 'Die styl van literêre analises en resensies'. Laasgenoemde hoofstuk is die grootste inhoudelike bydrae tot die heruitgawe.

Die boek het 'n baie sterk akademiese en taalfilosofiese inslag. Verskeie ander bronne word betrek by die inhoud, en daar word net soos in die 2003-uitgawe aan die einde van elke hoofstuk 'n lys met verdere leeswerk voorgestel. Hierdie leeslys is egter aansienlik bygewerk en dien terselfdertyd vir die leser as kosbare naslaanbron.

Die nuwe uitgawe het 'n ongedetailleerde inhoudsopgawe. 5.3 Stylvlakke: meer of minder formeel bestaan byvoorbeeld uit nege onderafdelings, naamlik (1) Stylbreuke; (2) Afstand tussen skrywer en leser; (3) Situasie, konteks en tekstipe; (4) Verbleking of verandering in betekenis; (5) Geweldstaal (krygstaal, taalmilitarisme, oorlogstaal); (6) Woorde wat geweld suggereer (selfs idealiseer); (7) Gepaste toon deur woordkeuse; (8) Tekstipe; en (9) 'n Geloofwaardige toon, maar die onderafdelings word nie in die boek se inhoudsopgawe aangedui nie. 'n Leser wat spesifiek na byvoorbeeld inligting oor geweldstaal op soek is, sal dus nie onmiddelik weet dat dit onder die afdeling Stylvlakke bespreek word nie. Nie al hierdie opskrifte (bv. krygstaal, taalmilitarisme of verbleking) word in die indeks opgeneem nie. Dit is dus vir ' $n$ leser onmoontlik om hierdie inligting via die inhoudsopgawe of indeks op te spoor of na te slaan sonder om die hele boek deur te gaan nie. 
Praktiese oefeninge maak teoretiese inligting konkreet en illustreer die teorie goed.

Die boek is nie net 'n handboek nie maar ook 'n naslaanbron wat verwysings na ander belangrike werke oor die bepaalde onderwerpe vir die leser aanbied.

Die enigste kritiek is dus dat die boek nie die magdom inligting wat daarin opgesluit is onmiddellik vir die leser (wat nie telkens die boek van begin tot einde gaan lees nie) ontsluit nie (bv. deur 'n gedetailleerde inhoudsopgawe).

\section{Literatuurverwysings}

Cochrane, N., 2004, 'Stylboek: riglyne vir paslik skryf - 'n resensie', Tydskrif vir Letterkunde 41(1), 181-182.

Venter, M., 2004. 'Gepaste styl laat 'n teks kommunikeer', Literator 25(2), 151-153

Vorster, J., 2003, 'Stylboek wys styl is inderdaad ' $n$ tameletjie', Die Burger, besigtig op 20 Oktober 2015 by http://152.111.1.87/argief/berigte/dieburger/2003/10/20/ DB/11LDNk/05.html 